\title{
Decomposition of industry structural shifts and reconstruction research based on share analysis
}

\author{
Yulia Vertakova ${ }^{1, *}$, Maria Klevtsova ${ }^{1}$, and Anna Rushkova ${ }^{1}$ \\ ${ }^{1}$ Southwest State University, 94, 50 Let Oktyabrya str., 305004 Kursk, Russia
}

\begin{abstract}
The current stage of economic development is characterized by the need to adjust the structural proportions of the development of individual industries. Particular attention should be paid to priority sectors, in particular, industries in the manufacturing sector, the ones changing the development trajectory from the raw material concept to the innovation model. The research also highlighted high-income and low-income activities, as well as the industry differentiation in terms of the level of concentration and labour resources, the dynamics of changes in structural proportions was investigated. The goal of the article is to decompose structural changes in sectors of the economy in certain regions of the Russian Federation by elements of employment, output and residual component. On the basis of a modified structural share analysis, decomposition of the structural elements of economic development was carried out on the basis of an analysis of structural proportions. As a result, the authors determined the relationship between economic growth and structural shifts for individual components. Approbation of the research conducted on the example of the regions of the Russian Federation. The calculation of shifts in the industry due to changes in the share of employment by type of activity and due to changes in the structure of output has been carried out. A mapping of changes in the structural proportions of the regional economy was also carried out, and changes in the structural proportions in individual sectors of the industrial and nonindustrial sectors were analyzed on the basis of selected components.
\end{abstract}

\section{Introduction}

In modern society in the Russian Federation, in the period of adaptation to a dynamically changing economy, the main trends in the formation of concepts for the development of territories are associated with the implementation of re-industrialization processes and are aimed at finding a new economic model, a new economic development strategy associated with structural transformations in priority sectors. At the current level of instability of the external environment in the framework of the implementation of the policy of import substitution and technological development, it is advisable to focus on the use of internal potential and, in particular, on the industrial development of the regions.

\footnotetext{
*Corresponding author: vertakova7@ya.ru
} 
Re-industrialization process has a direct impact on the dynamics of the individual components and structural change in the proportions of industrial development in the regions, which in turn stimulates structural transformation of certain activities.

The structural component of the regional economy in terms of identifying and justifying the role of cities also occurred in the works of V. Kristalller, I. Risin [1], Yu. Treshchevsky and others $[2,3]$. V. Kristaller tried to formulate a hypothesis about the regularity of the location of cities and their connection with size. In his works a "theory of central places" was formed, according to which cities are arranged in a hierarchical order depending on size (in terms of population). Already much later, Jacobs proposed and confirmed the hypothesis that the city is a source of economic growth.

The structure of the economy of any country is characterized by the presence of disproportions and its uneven development. The structural aspect of economic development is expressed in the appearance of qualitative changes in the economy of the economic system, where the resulting component of structural transformations is the appearance of structural changes characteristic of any type of economy.

Structural changes are interrelated with the economic cycle. During the crisis, not only is the death of the old branches of production, but also the emergence of new ones that are carriers of scientific and technological progress. This explains the need for government regulation of the process of resource allocation in high-tech industries, the search for productive methods and tools for regulating structural changes.

The study of the dynamics of structural changes economists are engaged in over a long period of time, for example, Clark K. made a significant contribution to the theory of sectoral development, Kemeny T., Storper M. [4]. Structural Transformation from the Viewpoint of Researchers MacMilan M., Rodrik D., and Sepulveda C. [5] not always directly related to economic growth, however, Kuznets S. [6] showed a relationship between economic growth and the restructuring process, and the economist Deytrich A. [7] proved that total economic growth is the cause of structural changes .

In many countries, a re-industrialization strategy is being implemented, aimed at improving the competitiveness and innovativeness of the economy and reducing the manufacturing industry, as well as the growth of the service sector (the third party economy). In the Russian Federation, the priority direction of re-industrialization is the transition from a raw material development model to an innovative one, which is associated with modern economic policies.

The regional economy has received a new life and additional research field, trying to combine its positions with the doctrines of economic growth. External returns to scale are qualitatively different from internal ones. It does not matter for what reason - due to the size of the participating firms or their significant number - the high level of concentration of local labour resources allows for external economies of scale for firms in a particular sector. This is called localization economics. The strength of these local externalities is not the same and may change over time, they appear stronger in some sectors of the economy and weaker in others. Such economies of scale include factors that reduce the average cost of production in the locality. The theory of localization economics can be supplemented by taking, for example, the shape of the market into account.

According to Sayago-Gomez and Stayer (2015) [8], LQs (Location Quotient) of economic activity is mainly used for industries that either create unique products for the regional economy, and also to determine the most export-oriented industries and promising areas of development of activities in the region. Implementing the LQ tool allows you to match spatial patterns of industrial concentration, while a study of changes in LQ provides useful information about whether each type of economic activity is increasing.

Externalities, if they are characterized by the side effects of knowledge between firms in a spatially concentrated industry, are known as "Marshall - Arrow -Romer" (MAR) effects. 
IDA theory in a dynamic context (Glaeser, Henderson, 2017) [9] predicts that local monopoly is better for growth than local competition, because local monopoly limits the flow of ideas for others and thus allows for innovation.

Porter M., Stern S. [10] also wrote about the importance of localization in economics, offering the concept of competitive advantage to countries. He pointed out that the side effects of knowledge in specialized industries, which differ in geographic concentration, stimulate economic growth.

The question of the relationship of the process of structural transformation and economic growth is quite controversial now. For identification of the level and vector of the structural transformation components influence on economic growth, we propose to use a modification of the shift-share analysis considered in R. Keller's work, which reflects the effect of changes in individual components of the structural transformation on economic growth [11]. In our study, it is proposed to use as the main elements of the structure: 1) the structure of employment by type of activity (component for employment) and 2) the level of income for certain types of activity, expressed in the volume of goods shipped or the provision of services in monetary terms (the "income" component). The final indicator is the level of economic growth in the region, estimated using the gross regional product (GRP) indicator.

The process of structural transformation in the country is affected by changes in the level of employment and income of individual regions, and in turn affects the structural changes in these regions. Structural transformation is not always directly related to economic growth.

Structural changes have attracted the attention of economists for a long time. Andergassen, R., Nardini, F., Ricottilli, M. (2018) [12] showed a relationship between economic growth and the restructuring process. They also noted that among various factors, technological progress is a priority for economic growth and structural change. Also, overall economic growth is the cause of structural changes.

In many countries, there is currently a process of re-industrialization, aimed at reducing the manufacturing industry and the growth of the service sector.

Therefore, attention to the study of directions, provoking's change also increases (Peneder) [13].

We have presented a phased study and decomposition of structural proportions of industry in Russia based on structural share analysis.

\section{Materials and Methods}

The scientific research by the authors was conducted in the following areas: analysis of the elements of the structure of the economy and analysis of the relations between them based on statistical methods, economic database and localization coefficients; as well as an assessment of the dynamics of the industrial structure of the regional economy based on structural shear analysis.

Structural share analysis was tested by us based on the implementation of a series of successive stages $[14,15]$. At the initial stage of the study, we determined the type of economic activity in which a particular region specializes on the basis of the localization coefficient. Secondly, we analyzed the impact of changes in the structure of employment on income in the region. Third, a comparison was made of the levels of output in a specific type of economic activity with the average output in the region. Finally, conclusions are made on the impact of structural transformation on employment and production in the region. 
In the classical version of the shift-share analysis is considered as a decomposition of the total change in industries into three elements: the effect of national growth, the effect of industrial development and the local effect.

At the first stage of the study, we carried out a decomposition of the elements that affect economic growth based on the following formula [1]:

$$
\bar{w}_{\mathrm{t}+1}-\bar{w}_{\mathrm{t}}=\underbrace{\sum_{\mathrm{i}=1}^{\mathrm{i}}\left(\frac{E_{\mathrm{i}}}{E}\right)_{\mathrm{t}} \cdot \Delta \bar{w}_{\mathrm{i}}}+\underbrace{\sum_{\mathrm{i}=1}^{\mathrm{i}} \bar{w}_{\mathrm{it}} \cdot \Delta\left(\frac{E_{\mathrm{i}}}{E}\right)}+\underbrace{\sum_{\mathrm{i}=1}^{\mathrm{i}} \Delta \bar{w}_{\mathrm{i}} \cdot \Delta\left(\frac{E_{\mathrm{i}}}{E}\right)}
$$

Income component Employment component Residual component

Where $\mathrm{i}$ - type of economic activity according to type of activity, $\Delta$ - changes from 2008 to $2016, \bar{W}$ - real "income" in the region, $\bar{W}_{i}$ - real income (in prices of 2016) by types of economic activity in a particular region, $E$ - number of people employed in the region, $E i$ - the number of people employed in a particular type of economic activity in the region, $t$ - period 2008, $t+1$ - the period 2016 year.

The formula consists of 3 components: 1 component reflects the impact of the income component for certain types of activities on the economic growth of the region as a whole. If it is positive, then income in a certain type of activity increased during the study period, component 2 shows the effect of changes in the structure of employment on the economic development of the region, component 3 is residual, shows the combined effect of changes in the structure of employment and the "income" part, although directly it does not reflect the influence of either one or the other component, therefore it is less significant.

The sum of the three components for all activities shows the change in the economic development of a particular region.

\section{Results}

Stage I Decomposition into separate structural elements. Structural share analysis was carried out on the basis of a number of iterations. We should calculate 3 components: the impact of the income, : the impact of the employment, residual component.

Stage II. Evaluation of the structural component of "income".

Analysis of the impact of the "income" component on the dynamics of the structural transformation of the region as a whole and of the industrial complex, in particular.

Based on the assessment of changes in the volume of goods shipped and services rendered, the main areas of "specialization" were identified, for example, in the Kursk region and from the industrial complex - manufacturing, from non-industrial - agriculture, forestry and hunting, services, and wholesale and retail trade in the Russian Federation.

Table 1. Assessment of the impact of the structural component of "income" on economic growth in the regions of the Russian Federation (2008-2016)

\begin{tabular}{|l|l|l|r|r|r|r|r|}
\hline № & \multirow{2}{*}{$\begin{array}{l}\text { Type of } \\
\text { activity }\end{array}$} & \multicolumn{1}{|c|}{ Activities } & \multicolumn{5}{|c|}{ Regions } \\
\cline { 3 - 8 } & & $\begin{array}{l}\text { Kursk } \\
\text { Region }\end{array}$ & $\begin{array}{l}\text { Belgorod } \\
\text { Region }\end{array}$ & $\begin{array}{l}\text { Tambov } \\
\text { Region }\end{array}$ & $\begin{array}{l}\text { Voronezh } \\
\text { Region }\end{array}$ & $\begin{array}{l}\text { Lipetsk } \\
\text { Region }\end{array}$ \\
\hline 1 & $\mathrm{~A}$ & $\begin{array}{l}\text { Agriculture. } \\
\text { forestry and } \\
\text { hunting }\end{array}$ & 488.53 & 620.75 & 486.12 & 465.97 & 745.68 \\
\hline 2 & $\mathrm{~B}$ & Mining & -8.72 & -40.13 & 0.00 & 0.06 & 0.70 \\
\hline 3 & $\mathrm{C}$ & $\begin{array}{l}\text { Manufacturing } \\
\text { industries }\end{array}$ & 233.82 & 718.42 & 355.04 & 1093.48 & 5000.92 \\
\hline 4 & D-E & $\begin{array}{l}\text { Production and } \\
\text { distribution of } \\
\text { electricity. gas. }\end{array}$ & -11.08 & -4.57 & -0.97 & 15.80 & 32.62 \\
\hline
\end{tabular}




\begin{tabular}{|l|l|l|r|r|r|r|l|}
\hline & & and water & & & & & \\
\hline 5 & F & Building & 17.56 & -44.45 & 2.47 & 109.23 & 176.52 \\
\hline 6 & G & $\begin{array}{l}\text { Wholesale and } \\
\text { retail trade }\end{array}$ & 461.78 & 486.70 & 1342.48 & 1804.72 & 2121.97 \\
\hline 7 & I. K-S & Services & 383.46 & 1368.45 & 413.79 & 2954.75 & -727.38 \\
\hline 8 & H. J & $\begin{array}{l}\text { Transport and } \\
\text { communication }\end{array}$ & -1.84 & 2.52 & -1.79 & -6.10 & 11.39 \\
\hline 9 & Total & & 1563.51 & 3107.68 & 2597.14 & 6437.91 & 7362.43 \\
\hline
\end{tabular}

The impact of changes in the structural component of "income" for each type of activity on the final indicator of regional development: the maximum effect in the Kursk region has the following activities: A, C, G, I, K-S, in the Belgorod region - A, I, K-S, in Tambov regions - A, G, in the Voronezh region - C, G, I, K-S, in the Lipetsk region - C, G.

Stage III. Evaluation of the structural component of "employment".

Diagnostics of the specialization of regions in employment in certain types of activities and the study of the impact of structural changes in this area on the structural transformation of the region in Russia. Kursk region - agriculture, forestry and hunting, manufacturing, wholesale and retail trade, construction; Belgorod region - agriculture, forestry and hunting, manufacturing, construction, trade; Tambov region - agriculture, forestry and hunting, manufacturing, wholesale and retail trade; Voronezh region manufacturing industry wholesale and retail trade, construction; Lipetsk region manufacturing, construction. The regions' specialization in income and employment overlaps in most parts.

Table 2. Assessment of the impact of the structural component of "employment" on economic growth in the regions of the Russian Federation (2008-2016)

\begin{tabular}{|c|c|c|c|c|c|c|c|}
\hline \multirow[t]{2}{*}{ № } & \multirow{2}{*}{$\begin{array}{l}\text { Type of } \\
\text { activity }\end{array}$} & \multirow[t]{2}{*}{ Activities } & \multicolumn{5}{|c|}{ Regions } \\
\hline & & & $\begin{array}{l}\text { Kursk } \\
\text { Region }\end{array}$ & $\begin{array}{l}\text { Belgorod } \\
\text { Region }\end{array}$ & $\begin{array}{l}\text { Tambov } \\
\text { Region }\end{array}$ & $\begin{array}{l}\text { Voronezh } \\
\text { Region }\end{array}$ & $\begin{array}{l}\text { Lipetsk } \\
\text { Region }\end{array}$ \\
\hline 1 & A & $\begin{array}{l}\text { Agriculture. } \\
\text { forestry and } \\
\text { hunting }\end{array}$ & 233.17 & 892.47 & 839.92 & 795.74 & 431.69 \\
\hline 2 & $\mathrm{~B}$ & Mining & 95.57 & 270.47 & 0.00 & 1.06 & 2.34 \\
\hline 3 & $\mathrm{C}$ & $\begin{array}{l}\text { Manufacturing } \\
\text { industries }\end{array}$ & 939.32 & 4861.87 & 595.74 & 1453.94 & 5461.42 \\
\hline 4 & D-E & $\begin{array}{l}\text { Production and } \\
\text { distribution of } \\
\text { electricity. gas. } \\
\text { and water }\end{array}$ & 151.98 & 38.86 & 23.81 & 86.81 & 44.10 \\
\hline 5 & $\mathrm{~F}$ & Building & 123.65 & 296.58 & 56.31 & 257.85 & 189.99 \\
\hline 6 & G & $\begin{array}{l}\text { Wholesale and } \\
\text { retail trade }\end{array}$ & 1417.64 & 2233.47 & 1737.71 & 3866.16 & 1200.06 \\
\hline 7 & I. K-S & Services & 63.05 & -2127.09 & -53.02 & -120.16 & -1320.21 \\
\hline 8 & H. J & $\begin{array}{l}\text { Transport and } \\
\text { communication }\end{array}$ & 20.50 & 17.14 & 16.26 & 27.40 & 22.87 \\
\hline 9 & Total & & 3044.86 & 6483.77 & 3216.73 & 6368.80 & 6032.26 \\
\hline
\end{tabular}

The impact of changes in the structural component of "employment" for each activity on the final indicator of regional development: the maximum effect in the Kursk region $\mathrm{n}$ (Russia) have activities: A, C, G, in the Belgorod region (Russia) - C , G, in the Tambov region (Russia)- A, G, C , in the Voronezh region (Russia)- A, C, G , in the Lipetsk region (Russia)- C, G.

Stage IV. Estimation of residual component. 
We have identified the relationship between the specialization of regions in employment and income in certain types of activities (Table 3-4). However, in some areas there is an inverse relationship, income growth - a reduction in the proportion of employees, which indicates an increase in operating efficiency and increase in labor productivity, in particular, this trend is observed in the services sector.

Table 3. Assessment of the effect of the residual structural component on economic growth in the regions of the Russian Federation (2008-2016)

\begin{tabular}{|l|l|l|r|r|r|l|l|}
\hline № & \multirow{2}{*}{$\begin{array}{l}\text { Type of } \\
\text { activity }\end{array}$} & \multicolumn{1}{|c|}{ Activities } & \multicolumn{5}{|c|}{ Regions } \\
\cline { 3 - 8 } & & $\begin{array}{l}\text { Kursk } \\
\text { Region }\end{array}$ & $\begin{array}{l}\text { Belgorod } \\
\text { Region }\end{array}$ & $\begin{array}{l}\text { Tambov } \\
\text { Region }\end{array}$ & $\begin{array}{l}\text { Voronezh } \\
\text { Region }\end{array}$ & $\begin{array}{l}\text { Lipetsk } \\
\text { Region }\end{array}$ \\
\hline 1 & A & $\begin{array}{l}\text { Agriculture. } \\
\text { forestry and } \\
\text { hunting }\end{array}$ & 159.30 & 471.46 & 547.43 & 384.11 & 155.65 \\
\hline 3 & B & Mining & -21.80 & -65.94 & 0.00 & 0.06 & -0.82 \\
\hline 4 & C & $\begin{array}{l}\text { Manufacturing } \\
\text { industries }\end{array}$ & 247.78 & 875.00 & 393.28 & 823.85 & -234.11 \\
\hline 5 & F & $\begin{array}{l}\text { Production and } \\
\text { distribution of } \\
\text { electricity. gas. } \\
\text { and water }\end{array}$ & -15.93 & -4.99 & -1.23 & 22.39 & -5.95 \\
\hline 6 & G & $\begin{array}{l}\text { Wholesale and } \\
\text { retail trade }\end{array}$ & 364.77 & 872.70 & 1933.17 & 2757.77 & 337.04 \\
\hline 7 & I. K-S & Services & 8.32 & -723.66 & -7.77 & -69.02 & -545.89 \\
\hline 8 & H. J & $\begin{array}{l}\text { Transport and } \\
\text { communication }\end{array}$ & -2.66 & 3.46 & -2.10 & -6.76 & -6.15 \\
\hline 9 & Total & & 759.86 & 1386.99 & 2865.39 & 4076.25 & -307.95 \\
\hline
\end{tabular}

The impact of changes in the residual component for each activity is analyzed similarly.

Table 4. Analysis of cumulative changes associated with structural transformation in the regions of the Russian Federation (2008-2016)

\begin{tabular}{|l|l|l|r|r|r|l|l|}
\hline № & \multirow{2}{*}{$\begin{array}{l}\text { Type of } \\
\text { activity }\end{array}$} & \multicolumn{1}{|c|}{ Activities } & \multicolumn{5}{|c|}{ Regions } \\
\cline { 4 - 8 } & & $\begin{array}{l}\text { Kursk } \\
\text { Region }\end{array}$ & $\begin{array}{l}\text { Belgorod } \\
\text { Region }\end{array}$ & \multicolumn{1}{l}{$\begin{array}{l}\text { Tambov } \\
\text { Region }\end{array}$} & $\begin{array}{l}\text { Voronezh } \\
\text { Region }\end{array}$ & $\begin{array}{l}\text { Lipetsk } \\
\text { Region }\end{array}$ \\
\hline 1 & A & $\begin{array}{l}\text { Agriculture. } \\
\text { forestry and } \\
\text { hunting }\end{array}$ & 881.01 & 1984.68 & 1873.46 & 1645.82 & 745.68 \\
\hline 3 & B & Mining & 65.05 & 164.40 & 0.00 & 1.18 & 0.70 \\
\hline 4 & C & $\begin{array}{l}\text { Manufacturing } \\
\text { industries }\end{array}$ & 1420.92 & 6455.29 & 1344.06 & 3371.27 & 5000.92 \\
\hline 5 & F & $\begin{array}{l}\text { Production and } \\
\text { distribution of } \\
\text { electricity. gas. } \\
\text { and water }\end{array}$ & 124.96 & 29.30 & 21.61 & 125.00 & 32.62 \\
\hline 6 & G & $\begin{array}{l}\text { Wholesale and } \\
\text { retail trade }\end{array}$ & 2244.19 & 3592.86 & 5013.37 & 8428.65 & 2121.97 \\
\hline 7 & I. К-S & Services & 454.83 & -1482.30 & 353.00 & 2765.57 & -727.38 \\
\hline 8 & Н. J & $\begin{array}{l}\text { Transport and } \\
\text { communication }\end{array}$ & 15.99 & 23.12 & 12.37 & 14.54 & 11.39 \\
\hline 9 & Итого & & 5368.23 & 10978.45 & 8679.26 & 16882.95 & 7362.43 \\
\hline
\end{tabular}


According to Table 4, the Voronezh region (Russia) is characterized by the maximum economic growth in terms of changes in the real GRP during the study period. This growth in the Voronezh region is largely due to high positive changes in the three sectors $\mathrm{C}, \mathrm{G}, \mathrm{I}, \mathrm{K}$ $-\mathrm{S}$, the minimum growth is characteristic of the Lipetsk region (Russia), which can be explained by a significant decline, as evidenced by the growth rate of individual indicators, which in real values are negative.

V Stage. The final stage.

At this stage, we carried out the final stage of the structural-equity analysis and showed the impact of changes in individual components of the structural transformation of the industrial and non-industrial sectors of the economy on the economic development of the region as a whole (Table 5, Fig. 1-5).

In order to construct maps reflecting the change in the structural proportions of the region for the two main components (employment and profitability), we will conduct an analytical calculation of individual technological indicators (Table 5).

Table 5. Structural-Share Analysis of Changes in the Regional Economy of the Russian Federation (2008-2016)

\begin{tabular}{|c|c|c|c|c|}
\hline \multirow[b]{2}{*}{$\begin{array}{l}\text { Type of } \\
\text { activity }\end{array}$} & \multicolumn{4}{|c|}{ Technological indicators of calculation } \\
\hline & $\begin{array}{l}\begin{array}{c}\text { Growth rate of } \\
\text { employment }\end{array} \\
\text { E2 = E1 / E0 }\end{array}$ & $\begin{array}{l}\text { The growth rate } \\
\text { of the indicator } \\
\text { "income" } \\
\text { w2 = w1 / w0 }\end{array}$ & $\begin{array}{l}\text { Percentage } \\
\text { change in } \\
\text { employment } \\
(\mathrm{E} 2-1) * 100 \%\end{array}$ & $\begin{array}{l}\text { The percentage } \\
\text { change in the } \\
\text { indicator "income" } \\
(\mathrm{W} 2-1) * 100 \%\end{array}$ \\
\hline \multicolumn{5}{|c|}{ Kursk Region } \\
\hline A & 1.33 & 1.68 & 32.61 & 68.32 \\
\hline $\mathrm{B}$ & 3.50 & 0.77 & 250.00 & -22.81 \\
\hline $\mathrm{C}$ & 2.06 & 1.26 & 105.97 & 26.38 \\
\hline $\mathrm{D}-\mathrm{E}$ & 2.44 & 0.90 & 143.75 & -10.48 \\
\hline $\mathrm{F}$ & 2.14 & 1.16 & 114.29 & 16.23 \\
\hline $\mathrm{G}$ & 1.79 & 1.26 & 78.99 & 25.73 \\
\hline I. K-S & 1.02 & 1.13 & 2.17 & 13.20 \\
\hline H. J & 2.44 & 0.87 & 144.44 & -13.00 \\
\hline \multicolumn{5}{|c|}{ Belgorod Region } \\
\hline A & 1.76 & 1.53 & 75.95 & 52.83 \\
\hline B & 2.64 & 0.76 & 164.29 & -24.38 \\
\hline $\mathrm{C}$ & 2.22 & 1.18 & 121.79 & 18.00 \\
\hline $\mathrm{D}-\mathrm{E}$ & 2.09 & 0.87 & 109.09 & -12.83 \\
\hline $\mathrm{F}$ & 1.92 & 0.86 & 92.31 & -13.84 \\
\hline $\mathrm{G}$ & 2.79 & 1.39 & 179.31 & 39.07 \\
\hline I. K-S & 0.47 & 1.34 & -52.88 & 34.02 \\
\hline H. J & 2.37 & 1.20 & 137.04 & 20.18 \\
\hline \multicolumn{5}{|c|}{ Tambov Region } \\
\hline A & 2.13 & 1.65 & 112.61 & 65.18 \\
\hline $\mathrm{B}$ & 0.00 & 0.82 & -100.00 & -18.45 \\
\hline $\mathrm{C}$ & 2.11 & 1.66 & 110.77 & 66.01 \\
\hline D-E & 2.27 & 0.95 & 127.27 & -5.18 \\
\hline $\mathrm{F}$ & 2.06 & 1.05 & 105.88 & 4.64 \\
\hline $\mathrm{G}$ & 2.44 & 17.42 & 144.00 & 1642.25 \\
\hline I. K-S & 0.98 & 1.15 & -1.88 & 14.66 \\
\hline H. J & 2.17 & 0.87 & 117.24 & -12.91 \\
\hline
\end{tabular}




\begin{tabular}{|l|r|r|r|r|}
\hline A & 1.82 & 1.48 & 82.43 & 48.27 \\
\hline B & 2.00 & 1.05 & 100.00 & 5.24 \\
\hline C & 1.75 & 1.57 & 75.34 & 56.66 \\
\hline D-E & 2.42 & 1.26 & 141.67 & 25.79 \\
\hline F & 2.50 & 1.64 & 150.00 & 63.55 \\
\hline G & 2.53 & 1.71 & 152.81 & 71.33 \\
\hline I. K-S & 0.98 & 1.57 & -2.34 & 57.43 \\
\hline H. J & 2.11 & \multicolumn{5}{|c|}{0.75} & 110.81 & -24.68 \\
\hline \multicolumn{5}{|c|}{ Lipetsk Region } \\
\hline A & 1.98 & 1.36 & 98.31 & 36.06 \\
\hline B & 2.00 & 0.65 & 100.00 & -34.93 \\
\hline C & 2.03 & 0.96 & 103.41 & -4.29 \\
\hline D-E & 2.08 & 0.87 & 107.69 & -13.50 \\
\hline F & 2.34 & 0.96 & 134.38 & -4.07 \\
\hline G & 1.58 & 1.28 & 57.63 & 28.09 \\
\hline I. K-S & 0.52 & 1.41 & -47.94 & 41.35 \\
\hline H. J & 2.16 & 0.73 & 115.63 & -26.90 \\
\hline
\end{tabular}

On the basis of Table 5 and Figure 1, we analyzed the relationship between the real economic growth of the regions and the "structural shifts" of the components. As a result of the research, it is possible to identify high-income, low-income activities, as well as industries with a high concentration of labour resources and low concentration.

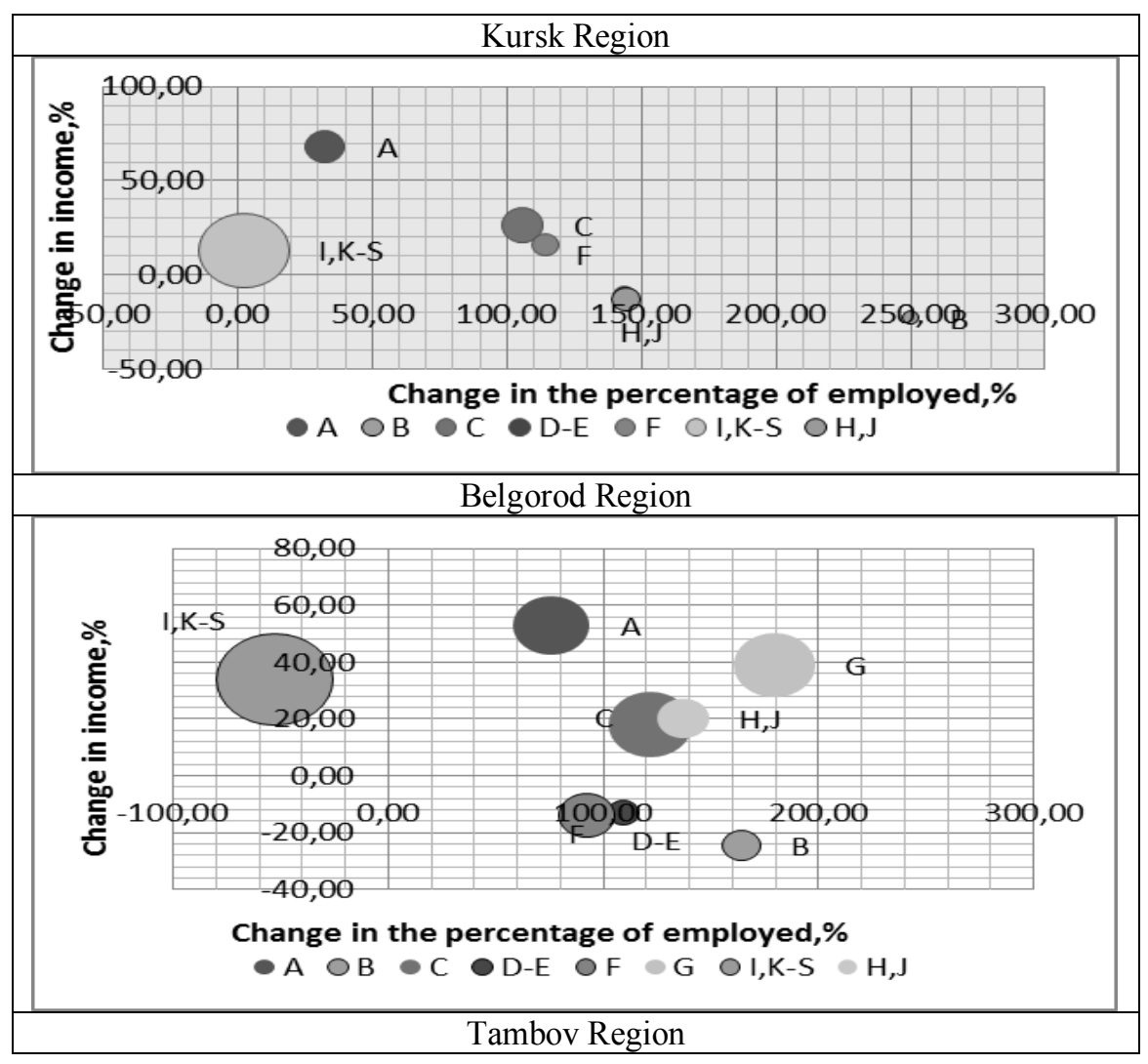




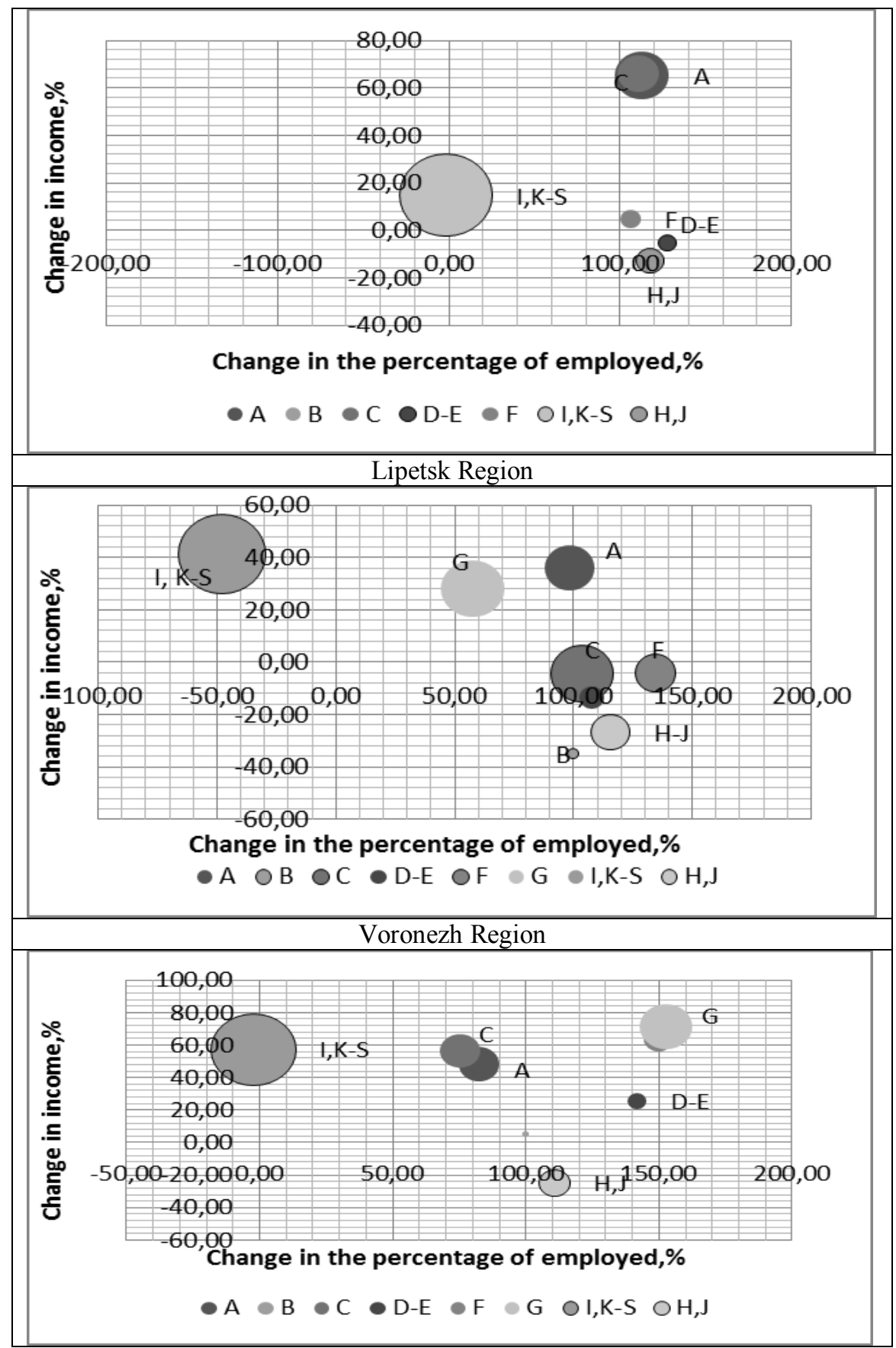

The black contour of the circles shows the negative impact of the component on the economic growth in the region.

The volume of the circle shows the share of employment in 2016.

Fig. 1. Mapping of changes in the structural proportions of the regional economy in the Russian Federation. 


\section{Discussion}

Figure 1 displays that all types of economic activity in the regions have shown positive economic growth since 2008, with the exception of the service sector in the Voronezh and Lipetsk regions of the Russian Federation. On the one hand, growth is positive, but on the other hand, it is necessary to compare the level of profitability of each specific industry and the average level of profitability of the industry and the level of national income.

Analysis of the distribution of employment showed that during the study period, specialization in the field of employment varied between the regions. Although the greatest positive effect of economic activity varied across regions, it was mainly related to agriculture (A) and industry and energy (B-E), or trade-related activities (G).

We analyzed the interrelation between the real economic growth of the regions and the "structural shifts" of the components.

1. The study was isolated in high-income, low-income activities, as well as industries with a high concentration of manpower and lower their concentration.

2. During the study period, economic growth is observed in those regions that have a specialization in employment, close to specialization in income and in general regional specialization. These results are consistent with the findings of foreign economists.

3. The authors presented a comparison of the location quotient for various types of economic activity in the Russian Federation and the regions studied. It can be noted that in the regions there are some types of economic activity in which localization is higher than at the national level.

\section{Conclusions}

In conclusion, regarding employment and the average level of "income", it can be said that in those areas of economic activity where regions have a pronounced specialization, the average "income" is usually higher than the average income in the region. However, the study revealed that not all changes and shifts in employment between economic types provide a high income.

It is also noteworthy that shifts occurred not only in relation to high-income industries, but also in relation to activities with a low level of "income". For more developed regions in Russia, such a shift in employment may not have a large negative effect. At the same time, the situation in those regions that are characterized by a level of development below the average level can lead to negative consequences.

The study was carried out with financial support and on the basis of fulfillment of the state task of the Ministry of Education and Science of the Russian Federation No. 26.3546.2017 / "Development of the fundamentals of analysis and forecasting of structural and dynamic parameters of the regional economy based on the integration of Russian and international experience in managing territorial development and modern scientific doctrines".

\section{References}

1. S. Zheleznyakov, I. Risin, Economic annals-xxi, 166(7-8), 80-85 (2017) doi: 10.21003/ea. V166-16

2. Y. Vertakova, Y. Polozhentseva, M. Klevtsova, I. Ershova, Proceedings of the 30th International Business Information Management Association Conference, IBIMA 2017 - Vision 2020: Sustainable Economic development, Innovation Management, and Global Growth, I-IX, 1834-1843 (2017) 
3. S. Rastvortseva, Economic and social changes-facts trends forecast, 11(1), 84-99 (2018)

4. T. Kemeny, M. Storper, Regional Studies, 49(6), 1003-1018 (2015)

5. M. McMillan, D. Rodrik, C. Sepulveda, Structural Change, Fundamentals, and Growth: A Framework and Case Studies (2016)

6. S. Kuznets, The Theory and Experience of Economic Development Essays in Honour of Sir Arthur Lewis, 43-59 (2012) doi: 10.4324/9780203838518

7. A. Dietrich, Empir Econ, 43, 915-944 (2012)

8. J. T. Sayago-Gomez, Stair Working Papers. Technical Document Series (2015)

9. E. Glaeser, J. V. Henderson, Journal of Urban Economics, 98, 1-5 (2017)

10. M. Delgado, M. E.Porter, S. Stern, Research Policy, 43(10) (2014) 10.1016/j.respol.2014.05.007

11. R. Keller, Monthly Labor Review, 26-38 (2009)

12. R. Andergassen, F. Nardini, M. Ricottilli, B. E. Journal of Macroeconomics, 18(2) (2018) doi: 20170195 10.1515/bejm-2017-0095

13. M. Peneder, Cambridge Journal of Economics, 41(3) (2017) doi: 829-858 10.1093/cje/bew025

14. Y. Vertakova, V. Plotnikov, Economic Annals-XXI, 166(7-8) 4-10 (2017)

15. S. Bodrunov, V. Plotnikov, Proceedings of the 30th International Business Information Management Association Conference, IBIMA 2017 - Vision 2020: Sustainable Economic development, Innovation Management, and Global Growth, 2658-2665 (2017) 